\title{
Implementasi Budaya Guyub Rukun di SMK N 1 Donorojo Pacitan melalui Kegiatan Kemasyarakatan Dalam Penanganan Pandemi Covid-19*
}

\author{
Bambang Hadi Sucipto ${ }^{1}$ \\ SMK N 1 Donorojo Pacitan, Jawa Timur \\ d \\ $\underline{10.15408 / \text { sjsbs.v7i8.15700 }}$
}

\begin{abstract}
:
This study aims to explore the concept of guyub rukun culture implemented by SMK 1 Donorojo Pacitan in handling, preventing the spread of Covid-19 in Pacitan Regency. Furthermore, this research explores the complexities that are in it, with cultural, vocational and social education perspectives in training students; and the collaboration of the citizens of SMKN 1 Donorojo Pacitan with the community and the government of Pacitan Regency in the mass production of cloth masks to prevent Covid-19 and overcome the scarcity of masks. This research uses a qualitative type, with an interdisciplinary approach that combines field studies, experimental, community service, and culture. The study was conducted in March 2020 to May 2020, with the spatial constraints of Pacitan Regency. The results of the research show that in social-based community activities, guyub rukun through harmony in making masks by SMKN 1 Donorojo Pacitan has complexity. The complexity is often not realized, because basically, the needs of the human cosmos are mutual assistance. Not only in terms of the human cosmos, but activities also carried out by SMKN 1 Donorojo Pacitand can bring a sense of harmony, a sense of unity, enthusiasm, and communal optimism, especially from the people of Pacitan Regency in facing the Covid-19 pandemic.

Keyword: guyub rukun; SMK N 1 Donorojo Pacitan; community activities; handling of the Covid-19 pandemic
\end{abstract}

\begin{abstract}
Abstrak:
Penelitian ini bertujuan untuk mengeksplorasi konsep budaya guyub rukun yang diterapkan oleh SMKN 1 Donorojo Pacitan dalam penanganan, pencegahan penyebaran Covid-19 di Kabupaten Pacitan. Lebih lanjut, penelitian ini mengeksplorasi kompleksitas yang ada di dalamnya, dengan sudut pandang budaya, pendidikan vokasi, dan pendidikan kemasyarakatan dalam melatih siswa; dan kerja sama warga SMKN 1 Donorojo Pacitan dengan masyarakat serta pemerintah Kabupaten Pacitan dalam produksi massal masker kain guna pencegahan Covid-19 dan mengatasi kelangkaan masker. Penelitian ini menggunakan jenis kualitatif, dengan pendekatan interdisipliner yang memadukan studi lapangan, eksperimental, pengabdian kemasyarakatan, dan kebudayaan. Penelitian dilakukan pada Maret 2020 hingga Mei 2020, dengan batasan spasial Kabupaten Pacitan. Hasil penelitian menunjukkan bahwasanya dalam kegiatan kemasyarakatan berbasis budaya guyub rukun melalui pembuatan masker oleh SMKN 1 Donorojo Pacitan ini memiliki kompleksitas. Kompleksitas tersebut sering kali tidak disadari, karena memang pada dasarnya kebutuhan kosmos manusia adalah saling membantu. Tidak hanya dalam hal kosmos manusia, kegiatan yang dilakukan oleh SMKN 1 Donorojo Pacitan dapat memunculkan rasa kerukunan, rasa kesatuan, semangat dan optimisme secara komunal khususnya dari masyarakat Kabupaten Pacitan dalam menghadapi pandemi Covid-19.
\end{abstract}

Kata kunci: budaya guyub rukun; SMK N 1 Donorojo Pacitan; kegiatan kemasyarakatan; penanganan pandemi Covid-19

\footnotetext{
*Diterima: 11 April 2020, Revisi: 12 Juli 2020, Diterbitkan 12 Agustus 2020.

${ }^{1}$ Bambang Hadi Sucipto adalah Kepala Sekolah SMK N 1 Donorojo Pacitan, Jawa Timur.
} 


\section{A. PENDAHULUAN}

Indonesia merupakan negara yang terkenal akan budayanya. Lebih lanjut, bentuk kebudayaan tidak hanya melalui artefak, namun juga dari sifat, tindakan, kebiasaan, dan perilaku masyarakatnya. Keramahan masyarakat Indonesia memberikan alasan tentang sebutan Negara Ketimuran yang dimiliki oleh Indonesia. Hal tersebut memberikan beberapa seloroh dari tokoh budayawan, yang mengatakan bahwa Indonesia merupakan negara ternyaman, dengan penduduknya yang ramah ${ }^{2}$.

Keramahan masyarakat Indonesia sebagai salah satu bentuk budaya berkelindan dengan istilah yang familiar dalam masyarakat Jawa untuk menyebut tentang kebersamaan, kedamaian, dan kerukunan, yaitu "guyub rukun". Guyub rukun jika dikaji secara mendalam ternyata memiliki makna yang mendasar. Guyub artinya kebersamaan sedangkan rukun memiliki makna keselarasan; tanpa pertikaian atau menghindari pertikaian. ${ }^{3}$ Guyub rukun diibaratkan mlaku karo lembehan (berjalan dengan ayunan tangan), maksudnya adalah terdapat kebersamaan dalam mengarungi kehidupan bermasyarakat. ${ }^{4}$ Guyub rukun sejatinya merupakan ruh kehidupan yang bisa dibayangkan andai kata guyub rukun ini terjalin diseluruh Indonesia, maka mantra sakti Persatuan yang pernah diucapkan Sang Patih Gajah Mada akan hidup kembali, sehingga berpeluang mewujudkan masyarakat yang guyub rukun didasari oleh sikap saling menghormati, empati, dan tepo seliro.

SMK N 1 Donorojo Pacitan, Jawa Timur, mencoba menerapkan konsep guyub rukun dalam menghadapi pandemi Covid-19 di Indonesia, khususnya di Kabupaten Pacitan. Hal tersebut didasari pada konsep sekolah kejuruan yang siap memberikan tenaga kerja terbaik, mempersiapkan individu untuk berkontribusi secara nyata bagi kehidupan di Indonesia, dan mempersiapkan pekerja yang akan membawa kejayaan Indonesia. Selain itu, konsep budaya guyub rukun sesuai dengan visi dan misi SMKN 1 Donorojo Pacitan yaitu "Sekolah yang Berkarakter, Kompeten, Peduli Lingkungan, dan Siap Kerja". SMK N 1 Donorojo Pacitan memiliki pengamalan konsep guyub rukun, yaitu dengan melakukan kegiatan kemasyarakatan melalui produksi massal masker sebagai upaya pencegahan dan penyebaran Covid-19.

Covid-19 menjadi pandemi global setelah kemunculannya di akhir 2019 lalu di Wuhan, China. Covid-19 merupakan penyakit menular yang disebabkan oleh corona virus versi baru yang ditemukan pada akhir 2019 lalu. ${ }^{5}$ Identifikasi awal yang muncul dari gangguan yang dialami oleh individu yang terinfeksi virus COVID-19 yaitu berupa penyakit pernapasan ringan hingga sedang dan sembuh tanpa memerlukan perawatan

${ }^{2}$ Masykurotus Syarifah, “Budaya Dan Kearifan Dakwah,” al-Balagh : Jurnal Dakwah dan Komunikasi 1, no. 1 (2016): 23.

${ }^{3}$ Dennys Lombard, Nusa Jawa: Silang Budaya (Batas-Batas Pembaratan) (Jakarta: Gramedia Pustaka Utama, 2008); Dennys Lombard, Nusa Jawa: Silang Budaya (Warisan Kerajaan-Kerajaan Konsentris) (Jakarta: Gramedia Pustaka Utama, 2008).

${ }^{4}$ Dwiyasmono, “Karya Tari 'Solah' Refleksi Nilai-Nilai Budaya Jawa Dalam Kehidupan Kekinian," Jurnal Kawistara 5, no. 1 (2015); Lombard, Nusa Jawa: Silang Budaya (Warisan Kerajaan-Kerajaan Konsentris).

5 World Health Organization, "Coronavirus," last modified 2020, accessed 12 May, 2020, https://www.who.int/health-topics/coronavirus\#tab=tab_1. 
khusus. ${ }^{6}$ Covid-19 menjadi menakutkan karena persentase penularannya sangat cepat dan cenderung pada individu usia lanjut dan mereka yang memiliki riwayat masalah medis akut; yang mampu berkembang menjadi penyakit atau gangguan komplikasi. Kasus pertama virus corona awalnya diidentifikasi sebagai flu pada tahun 1960 dengan sekitar 500 pasien diidentifikasi mengalami gangguan yang menyerupai flu. ${ }^{8}$ Selanjutnya, corona diperlakukan sebagai virus yang tidak mematikan dan dianggap sederhana sampai tahun 2002. Pasca adanya Severe Acute Respiratory Syndrome (SARSCov) di China, para pakar mulai berfokus pada penyebab dan menemukan hasil apabila wabah ini diakibatkan oleh bentuk baru corona ${ }^{9}$. Pada tahun 2012, terjadi pula wabah yang mirip yakni Middle East Respiratory Syndrome (MERS-Cov) di Timur Tengah ${ }^{10}$. Dari kedua peristiwa itulah diketahui bahwa corona mampu bermutasi dengan cepat dan menjadi mematikan karena sampai Mei 2020 belum ada vaksin yang mampu menanganinya. Hal tersebut secara tidak langsung turut berkontribusi terhadap penyebaran Covid-19 di Indonesia yang jumlah pasien terinfeksi Covid-19 bertambah setiap harinya.

Gambar 1. Data penderita Covid-19

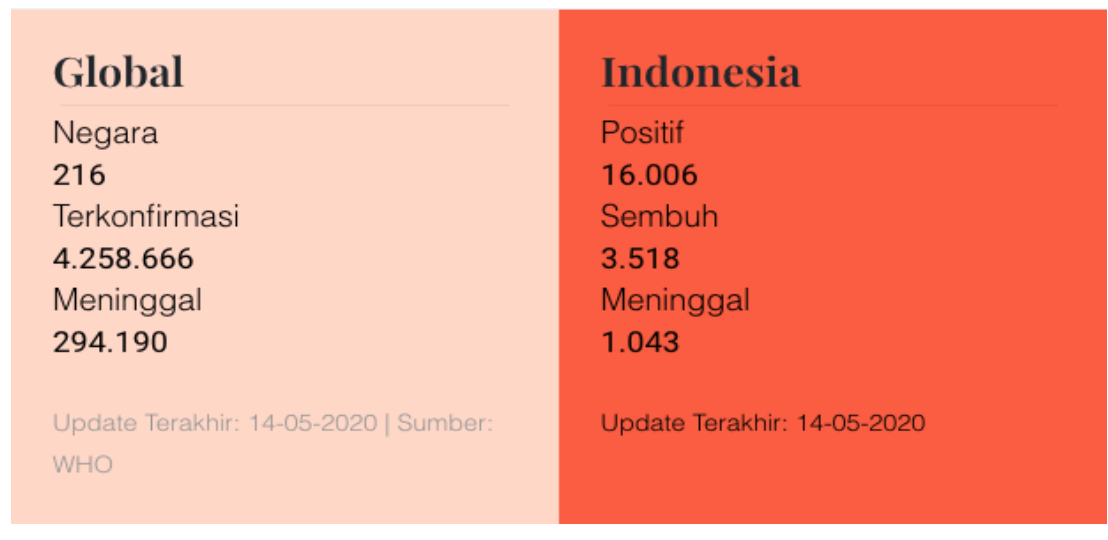

Sumber: Gugus penanganan Covid-19 Republik Indonesia ${ }^{11}$

Tentunya langkah preventif sudah dilakukan baik oleh pemerintah pusat maupun daerah, baik lembaga pemerintahan, lembaga pendidikan turut andil dalam penanganannya, termasuk SMKN 1 Donorojo Pacitan, Jawa Timur dengan konsep guyub rukunnya. SMKN 1 Donorojo Pacitan membantu Indonesia, khususnya Kabupaten Pacitan, untuk bersama-sama mengatasi kelangkaan masker. Selain itu, penggunaan

6 "Covid-19 Coronaviruses Pandemic," accessed May 13, 2020, https://www.worldometers.info/coronavirus/; Wang Zhou, ed., Coronavirus Prevention Handbook (Wuhan: Hubei Science and Technology Press, 2020).

7 Kemkes, “Tentang Novel Coronavirus (NCOV)," last modified 2020, accessed April 23, 2020, https://www.kemkes.go.id/resources/download/info-terkini/COVID-19/TENTANG NOVEL CORONAVIRUS.pdf; "Covid-19 Coronaviruses Pandemic"; Zhou, Coronavirus Prevention Handbook; Scripps Research Institute, “COVID-19 Coronavirus Epidemic Has a Natural Origin,” Science Daily, last modified 2020, accessed April 23, 2020, https://www.sciencedaily.com/releases/2020/03/200317175442.htm.

${ }^{8}$ Dharmendra Kumar, Rishabha Malviya, and Pramod Kumar Sharma, "Corona Virus: A Review of COVID-19," Eurasian Journal of Medicine and Oncology 4, no. 2 (2020): 8-25.

${ }^{9}$ Ibid.

${ }^{10}$ Ibid.; Scripps Research Institute, “COVID-19 Coronavirus Epidemic Has a Natural Origin.”

11 “Sebaran Covid19," accessed May 15, 2020, https://covid19.go.id/. 
masker telah menjadi himbauan yang bersifat wajib oleh pemerintah dan WHO sebagai upaya pencegahan penyebaran Covid-19.

Dari penjabaran di atas, penelitian ini mencoba untuk mengeksplorasi konsep budaya guyub rukun yang diterapkan oleh SMKN 1 Donorojo Pacitan dalam penanganan, pencegahan penyebaran Covid-19 di Kabupaten Pacitan. Lebih lanjut, penelitian ini mengeksplorasi kompleksitas yang ada di dalamnya, dengan sudut pandang pendidikan dalam melatih siswa dan kerja sama warga SMKN 1 Donorojo Pacitan dan masyarakat Pacitan dalam produksi massal masker.

\section{B. TINJAUAN LITERATUR}

Budaya penelitian dalam menghadapi tekanan cenderung positif. Artinya, peneliti memiliki andil yang baik dalam mengungkap sudut pandang baru terhadap sebuah fenomena. Terdapat beberapa kecenderungan penelitian, antara lain penelitian kualitatif, penelitian eksperimen untuk pemecahan masalah, dan penelitian yang bersifat pengabdian dan kemasyarakatan yang bertujuan untuk membangun kekuatan masyarakat yang solid. Di dalam penelitian yang berbasis pengabdian dan kemasyarakatan, tidak melulu membahas soal kapasitas benda terhadap pemecahan masalah, namun juga terkait daya nalar dalam memetakan masalah tersebut.

Sudut pandang multiperspektif merupakan pilihan wajib, karena untuk pencegahan memerlukan antisipasi dari berbagai arah. Perlu koordinasi antara sponsor ${ }^{12}$, masyarakat ${ }^{13}$, komunitas ${ }^{14}$, dan pemerintah, dalam upaya preventif untuk mencegah dan menanggulangi fenomena. Di dalam permasalahan terkait Covid-19, terdapat beberapa penelitian. Penelitian yang dilakukan cenderung multiperspektif, yang memiliki keunikannya masing-masing. Seperti penelitian tentang kebijakan pemberlakuan lockdown sebagai antisipasi penyebaran Covid-19. ${ }^{15}$ Selain itu, kolaborasi dengan pemerintah selalu menjadi perbincangan yang hangat dalam penelitian terkait Covid-19. Hal tersebut dikarenakan sejatinya masyarakat membutuhkan tameng yang mampu melindungi dan memberi ketenteraman bagi jiwanya. ${ }^{16}$

\footnotetext{
12 Emily E. Wilcox, "Beyond Internal Orientalism: Dance and Nationality Discourse in the Early People's Republic of China, 1949-1954," Journal of Asian Studies 75, no. 2 (2016): 363-386.

${ }^{13}$ Hui Huang et al., "Serving Former Foster Youth and Homeless Students in College," Journal of Social Service Research 8376 (2018): 1-14, https://doi.org/10.1080/01488376.2018.1441096.

${ }_{14}$ Michael P Johnson, Community-Based Operations Research: Decision Modeling for Local Impact and Diverse Populations (Singapore: Springer, 2012); Vita Ruliana, Roekmijati W. Soemantojo, and Donna Asteria, "Assessing a Community-Based Waste Separation Program through Examination of Correlations between Participation, Information Exposure, Environmental Knowledge, and Environmental Attitude," ASEAN Journal of Community Engagement 3, no. 1 (2019): 1-27; Chau kiu Cheung and wing whung Ho, "Investing in Community Participation to Receive Social Support," Journal of Social Service Research 38, no. 1 (2012): 110123.

${ }^{15}$ Nur Rohim Yunus and Annissa Rezki, “Kebijakan Pemberlakuan Lock Down Sebagai Antisipasi Penyebaran Corona Virus Covid-19," SALAM: Jurnal Sosial dan Budaya Syar-i 7, no. 3 (2020).

16 Zahrotunnimah Zahrotunnimah, "Langkah Taktis Pemerintah Daerah Dalam Pencegahan Penyebaran Virus Corona Covid-19 Di Indonesia," SALAM: Jurnal Sosial dan Budaya Syar-i 7, no. 3 (2020).
} 
Penelitian terkait masker cenderung sedikit. Namun ada penelitian yang menarik terkait masker, khususnya bagaimana peran masker dan tata cara penggunaannya ketika melakukan ibadah. ${ }^{17}$ Masker tidak berdiri sendiri sebagai traktori dalam pencegahan penyebaran virus Covid-19. Perlu adanya kolaborasi dengan benda atau disiplin lain untuk semakin mampu mencegah Covid-19 dari berbagai arah. Selain memahami penyebarannya melalui media sosial, ${ }^{18}$ juga salah satunya dengan kesiapan masyarakat dan kiat dalam menjaga kesejahteraan jiwa dengan selalu berpikir optimis dan selalu mendekatkan diri kepada Tuhan Yang Maha Penyembuh. ${ }^{19}$

Dari tinjauan literatur di atas, maka posisi penelitian ini berada dalam penelitian interdisiplin. Hal tersebut dikarenakan penelitian ini berangkat dari isu budaya yaitu guyub rukun yang diimplementasikan melalui pembuatan masker dalam penanganan pandemi virus Covid-19. Lebih lanjut, penelitian ini memiliki kebaruan dan keaslian, karena belum ada yang mengawali penelitian dari sudut pandang budaya yang dikolaborasikan dengan keterampilan, pendidikan, dan penanganan bencana, dalam hal ini Covid-19.

\section{METODE PENELITIAN}

Penelitian ini menggunakan jenis kualitatif, dengan pendekatan interdisiplin ${ }^{20}$. Alasan pemilihan jenis dan pendekatan penelitian tersebut dikarenakan penelitian ini menggunakan lebih dari satu disiplin ilmu baik dalam analisis maupun praktik di lapangan. Penelitian ini tidak tergolong dalam penelitian pengabdian kemasyarakatan semata, yang hanya berfokus pada pelatihan dan pengembangan potensi masyarakat ${ }^{21}$. Namun penelitian ini turut membedah fenomena yang berangkat dari pengabdian kemasyarakatan tersebut dengan sudut pandang budaya dan tradisi Jawa. ${ }^{22}$ Oleh karena itu, penelitian ini memiliki kompleksitas pembahasan yang tinggi.

17 Syandri Syandri and Fadhlan Akbar, "Penggunaan Masker Penutup Wajah Saat Salat Sebagai Langkah Pencegahan Wabah Coronavirus Covid-19," SALAM: Jurnal Sosial dan Budaya Syar-i 7, no. 3 (2020).

${ }_{18}$ Muchammad Bayu Tejo Sampurno, Tri Cahyo Kusumandyoko, and Muh Ariffudin Islam, “Budaya Media Sosial, Edukasi Masyarakat, Dan Pandemi COVID-19," SALAM: Jurnal Sosial dan Budaya Syar-i 7, no. 5 (2020).

${ }^{19}$ Dana Riksa Buana, “Analisis Perilaku Masyarakat Indonesia Dalam Menghadapi Pandemi Virus Corona (Covid-19) Dan Kiat Menjaga Kesejahteraan Jiwa," SALAM: Jurnal Sosial dan Budaya Syar-i 7, no. 3 (2020); Mukharom Mukharom and Havis Aravik, "Kebijakan Nabi Muhammad Saw Menangani Wabah Penyakit Menular Dan Implementasinya Dalam Konteks Penanggulangan Coronavirus Covid-19," SALAM: Jurnal Sosial dan Budaya Syar-i 7, no. 3 (2020).

${ }^{20}$ A Tashakkori and J Creswell, "Mixed Methodology Across Disciplines," Journal Of Mixed Methods Research 2, no. 1 (2008): 1-5; Joe Moran, Interdisciplinarity (New York: Routledge, 2002); John W Creswell, Research Design Pendekatan Kualitatif, Kuantitatif, Dan Mixed (Yogyakarta: Pustaka Pelajar, 2010).

${ }^{21}$ Ram A. Cnaan and Carl Milofsky, eds., Handbook of Community Movements and Local Organizations (Singapore: Springer, 2007); Kerry J. Strand et al., Community-Based Research and Higher Education: Principles and Practices (New York: Jossey-Bass, 2003).

22 Vlad Petre Glăveanu, ed., The Palgrave Handbook of Creativity and Culture Research (United Kingdom: Palgrave Macmillan, 2016); Mario Carretero, Stefan Berger, and Maria Grever, eds., Palgrave Handbook of Research in Historical Culture and Education (United Kingdom: Palgrave Macmillan, 2017). 
Penelitian ini berlokasi di Kabupaten Pacitan, Jawa Timur, yang berlangsung pada Maret 2020 untuk identifikasi masalah, observasi, dan tinjauan data lapangan; April 2020 untuk produksi massal masker oleh SMKN 1 Donorojo Pacitan, juga dilakukan pendistribusian tingkat awal, ${ }^{23}$ dan Mei 2020 untuk finalisasi distribusi ke instansi kesehatan, instansi pendidikan, instansi daerah, instansi pemerintahan, dan masyarakat umum.

Pengumpulan data yang dilakukan pada bulan Maret 2020, menempatkan peneliti sebagai instrumen utama dalam penelitian. Peneliti sebagai instrumen utama menentukan teknik pengumpulan data dalam penelitian, yaitu observasi, wawancara, dan studi dokumentasi ${ }^{24}$. Observasi dilakukan terhadap kondisi Kabupaten Pacitan terhadap pandemi Covid-19 dan respons masyarakat global dalam menghadapi situasi pandemi Covid-19. Selanjutnya, dari observasi awal, data diperkuat dengan melakukan wawancara terhadap masyarakat di Kabupaten Pacitan, yang berisi respons mereka tentang langkah preventif penanganan Covid-19. Langkah terakhir dalam pengumpulan data adalah melakukan filtrasi keterbukaan dan potensi peserta didik dan fasilitas SMK N 1 Donorojo Pacitan, yang mampu dijadikan sukarelawan dan juga survei terhadap kesiapan media yang akan menjadi solusi pencegahan Covid-19 di Kabupaten Pacitan.

Data yang terkumpul dianalisis dengan menggunakan teknik analisis interaktif kontinuitas, di mana peneliti diperbolehkan untuk melakukan analisis data sejak pengumpulan data dilakukan ${ }^{25}$. Selanjutnya, data disajikan secara deskriptif disertai analitik dengan membawa sudut pandang budaya Jawa, yaitu guyub rukun.

\section{ANALISIS DAN PEMBAHASAN}

Budaya guyub rukun yang diaplikasikan oleh SMK N 1 Donorojo Pacitan memberikan angin segar bagi khasanah kebudayaan Indonesia. Hal tersebut dikarenakan, sebenarnya Indonesia tengah dihadapi pada era disrupsi yang mengancam kebudayaan lokal ${ }^{26}$. Globalisasi masuk dengan bebas melalui acara televisi, hiburan, dan gaya hidup remaja masa kini tanpa diikuti oleh pemahaman akan budaya lokal. Dengan adanya implementasi budaya guyub rukun oleh SMK N 1 Donorojo Pacitan di tengah pandemi Covid-19, dapat menjadi salah satu cara untuk mengembalikan dasar kebudayaan Indonesia sekaligus memiliki andil dalam penanganan Covid-19.

${ }^{23}$ Bridget Somekh, Action Research: A Methodology for Change and Development (Berkshire: Open University Press, 2006).

${ }^{24}$ Norman K. Denzin and Yvonna S. Lincoln, eds., The SAGE Handbook of Qualitative Research, Fifth Edit. (Los Angeles: Sage Publications, 2018).

25 Asher Shkedi, Introduction to Data Analysis in Qualitative Research (Singapore: Springer International Publishing, 2019).

${ }^{26}$ Sheri R. Klein, "Humor in a Disruptive Pedagogy Further Considerations for Art Educators," Art Education 66, no. 6 (2013): 34-39. 
Usia remaja merupakan usia pra-kematangan ${ }^{27}$. Beberapa tahun terakhir, kasus kenakalan remaja di Indonesia sedang marak-maraknya. Mulai dari geng motor, pelaku begal, dan klitih di Yogyakarta, serta vandalisme terjadi sebagai salah satu cara pelampiasan emosi yang dialami remaja. Kenakalan remaja memang bisa dianggap wajar dalam satu sisi, namun di sisi lain jika kenakalan tersebut merugikan banyak kalangan, maka hal tersebut perlu diwaspadai.

Budaya Jawa memberikan pendidikan olah rasa ${ }^{28}$, yang sebenarnya sangat dekat dengan kehidupan keseharian. Seperti halnya dalam gotong royong, selain diajarkan tentang saling membantu, gotong royong juga mengajarkan pendidikan tentang kepekaan baik inderawi dan batiniah ${ }^{29}$. Terdapat pula penanaman pendidikan sopan santun, olah tubuh, intonasi dalam berbicara dengan orang tua, dan pendidikan moral lainnya ${ }^{30}$. Namun ke semuanya tersebut, tidak serta merta tampak gamblang dalam tindakan kebudayaan, namun tersirat dan tidak banyak yang menyadari. Begitu pula dengan budaya guyub rukun, baik yang ada di desa-desa, maupun yang dilakukan oleh SMK N 1 Donorojo Pacitan.

Gambar 2. Kunjungan sebagai Dukungan dari Bupati Pacitan

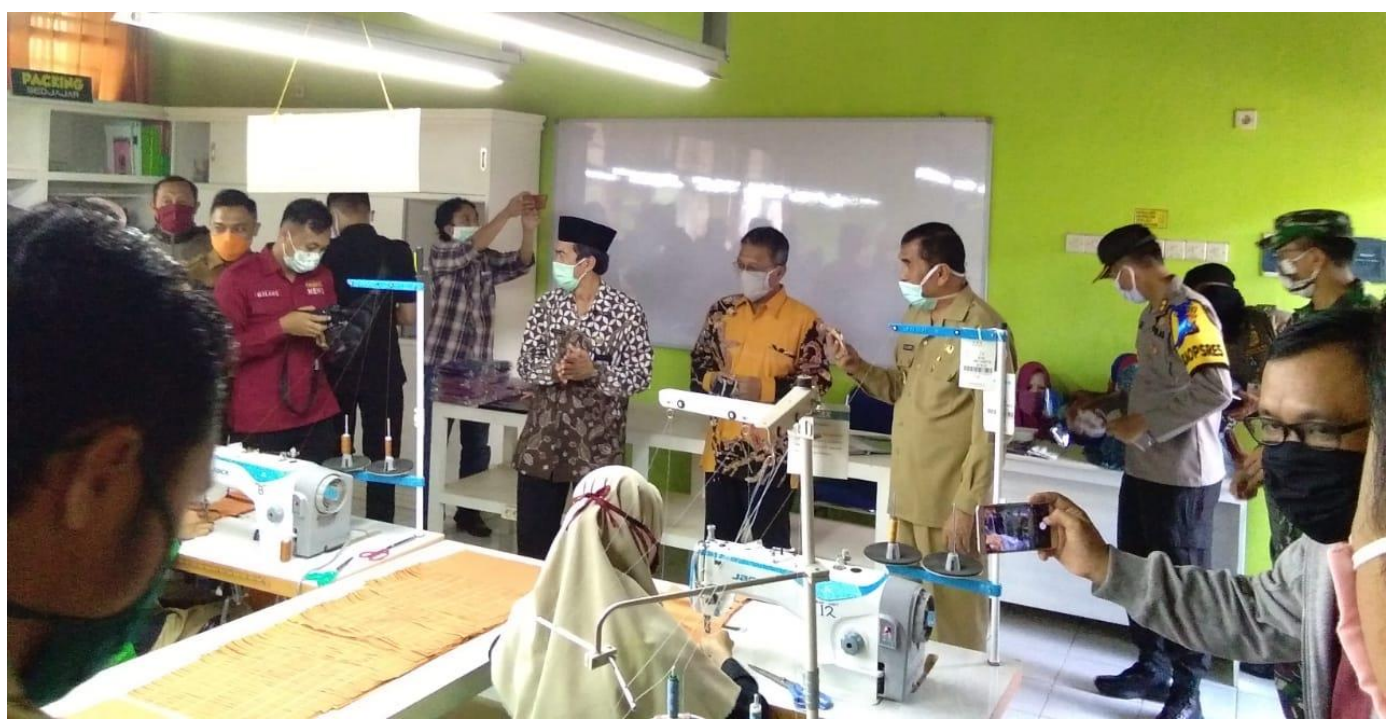

Sumber: Dokumentasi penulis, 2020

${ }^{27}$ Kaufman James and Robert J. Sternberg, The Cambridge Handbook of Creativity (New York: Cambridge University Press, 2010).

${ }^{28}$ Ika Amalia Kusumawardhani, Woro Kurnianingrum, and Naomi Soetikno, “Art Therapy Untuk Meningkatkan Kontrol Diri Pada Anak Didik Lapas," Jurnal Muara Ilmu Sosial, Humaniora, dan Seni 2, no. 1 (2018): 135; Moch. Anif Arifani, “Model Pengembangan Dakwah Berbasis Budaya Lokal," Jurnal Ilmu Dakwah: Academic Journal for Homiletic Studies 5, no. 15 (2010): 849-878, http://www.journal.uinsgd.ac.id/index.php/idajhs/article/view/425.

${ }^{29}$ Sue Winton, "The Appeal(s) of Character Education in Threatening Times: Caring and Critical Democratic Responses," Comparative Education 44, no. 3 (2018): 305-316; M. Thoriqul Huda, "Harmoni Sosial Dalam Tradisi Sedekah Bumi Masyarakat Desa Pancur Bojonegoro," Religió: Jurnal Studi Agama-agama 7, no. 2 (2017): 267-296.

${ }^{30}$ Clifford Geertz, The Interpretation of Cultures (New York: Basic Book, 1973); Ki Hadjar Dewantara, Karya Ki Hadjar Dewantara Bagian I: Pendidikan (Yogyakarta: Majelis Luhur Persatuan Taman Siswa, 2004). 
Budaya guyub rukun yang diinisiasi oleh SMK N 1 Donorojo Pacitan semakin menubuh manakala terjadinya kolaborasi antara sekolah, instansi pemerintah lokal, dan masyarakatnya. ${ }^{31}$ Pemerintah Kabupaten Pacitan secara apresiatif dan partisipatoris melalui kunjungannya, mampu memberikan kenyamanan para warganya di tengah kecemasan pandemi Covid-1932. Masyarakat menjadi nyaman dan merasa aman, karena pemerintah lokal Pacitan bersifat aktif dalam mendukung program pembuatan masker oleh SMK N 1 Donorojo Pacitan, sekaligus sebagai contoh perwujudan luaran budaya guyub rukun ${ }^{33}$.

Gambar 3. Salah satu prosesi pembuatan masker di SMK N 1 Donorojo Pacitan

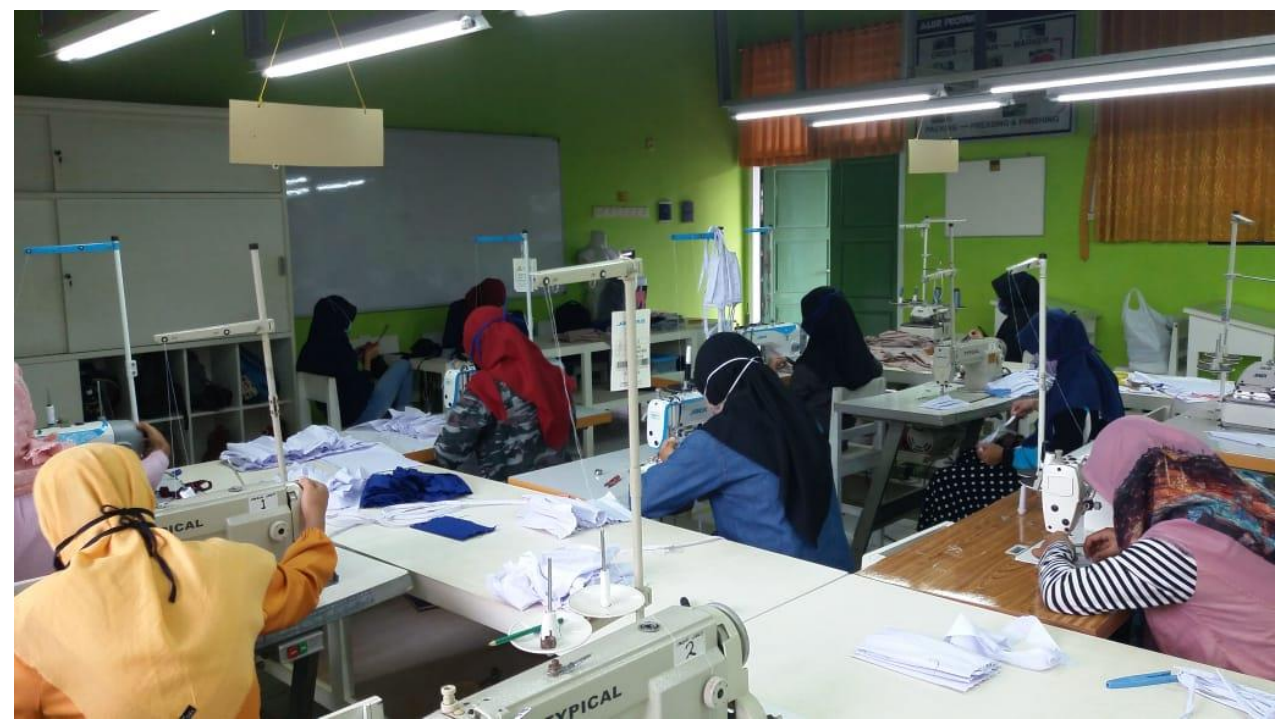

Sumber: Dokumentasi penulis, 2020

Fokus utama budaya guyub rukun yang dilakukan oleh SMK N 1 Donorojo Pacitan adalah untuk penanganan Covid-19 melalui pembuatan masker. Sesuai dengan anjuran Kementerian Kesehatan RI, semua orang disarankan untuk memakai masker kain ketika harus bepergian ke luar rumah, misalnya saat harus bekerja atau membeli kebutuhan bulanan. Juga rekomendasi terbaru dari WHO adalah dengan menyarankan penggunaan masker di seluruh kegiatan yang berada di luar rumah. ${ }^{34}$ Masker yang dibuat oleh SMK N 1 Donorojo Pacitan adalah masker kain. Masker kain tetap dapat menghalau sebagian percikan air liur yang keluar saat berbicara, menghela napas,

${ }^{31}$ Elaine Bratic Arkin, “Opportunities for Improving the Nation's Health through Collaboration with the Mass Media," Public Health Reports 105, no. 3 (1990): 219-223.

32 Sangmi Choi et al., "Online Donation Experiences, Donation Awareness, and Intention of Future Donation Among Teenagers in South Korea," Journal of Social Service Research 45, no. 5 (2019): 622-633, https://doi.org/10.1080/01488376.2018.1487363.

33 Dita Hommerová and Lucie Severová, "Fundraising of Nonprofit Organizations: Specifics and New Possibilities," Journal of Social Service Research 45, no. 2 (2019): 181-192, https://doi.org/10.1080/01488376.2018.1479678.

34 "Penggunaan Masker," The Jakarta Post, accessed May 15, 2020, https://www.thejakartapost.com/news/2020/04/06/face-masks-a-must-in-public-places-says-indonesiascovid-19-rapid-response-team.html. 
ataupun batuk dan bersin. ${ }^{35}$ Namun, selain itu, terdapat pendidikan tersirat dalam kegiatan pembuatan masker tersebut, yaitu tentang gotong royong, kerukunan, dan kekuatan tim dalam semangat penanganan Covid-19 melalui produksi massal masker untuk masyarakat. Istilah 'semangat' seperti terlihat biasa saja, namun ketika pandemi Covid-19 datang, istilah tersebut bagaikan mantra yang memiliki efek luar biasa. Seperti yang sudah diketahui, bahwasanya untuk bertahan dari Covid-19, individu harus memiliki sistem imun yang baik. ${ }^{36}$ Oleh karenanya, 'semangat' bekerja sama yang dilakukan antara segenap warga SMK N 1 Donorojo Pacitan dan masyarakat Kabupaten Pacitan dalam kampanye penanganan Covid-19 patut diapresiasi. Terutama SMK N 1 Donorojo Pacitan, para remaja yang merupakan siswa-siswi di sekolah tersebut mampu mengindahkan egosentrismenya dan melakukan aksi nyata untuk berkontribusi dalam pembuatan masker ${ }^{37}$. Mereka rela untuk meluangkan waktu untuk membantu sesama, khususnya masyarakat Kabupaten Pacitan dan seluruh masyarakat Indonesia dalam mengatasi kekurangan masker. Mereka tidak menyadari bahwasanya semangat yang ada dalam diri mereka secara tidak langsung tersalurkan melalui masker yang mereka buat. 38

Gambar 4. Masker model tali (untuk penggunaan hijab maupun biasa)

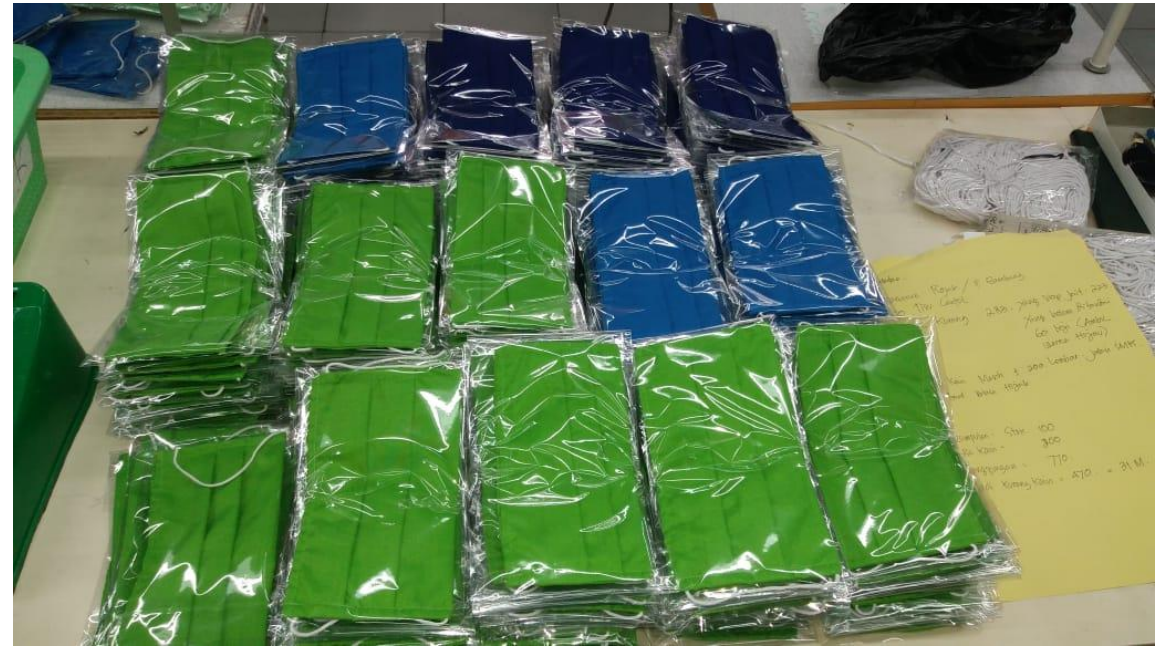

Sumber: Dokumentasi pribadi, 2020

\footnotetext{
35 “Jenis-Jenis Masker," accessed May 15, 2020, https://www.alodokter.com/inilah-pilihan-maskeruntuk-virus-corona.

${ }^{36}$ Kumar, Malviya, and Sharma, "Corona Virus: A Review of COVID-19"; Center for Disease Control and Prevention (CDC), "What You Need to Know about Coronavirus Disease 2019 (COVID-19)," Choice Reviews Online, 2020.

${ }^{37}$ K. E. Adolph and S. E. Berger, "Physical and Motor Development," in Developmental Science: An Advanced Textbook, ed. M. H. Bornstein and M. E. Lamb, 7th ed. (New York: Psychology Press/Taylor \& Francis, 2015), 261-333; M. Rutter and N. Garmezy, "Developmental Psychopathology," in Handbook Of Child Psychology, 4th ed. (New York: Wiley, 1983); María Celeste Dávila, "The Relationship between Social Networks and Volunteerism among Seniors," Journal of Social Service Research 44, no. 1 (2018): 38-49, https://doi.org/10.1080/01488376.2017.1395382.

${ }^{38}$ Linda Connor and Adrian Vickers, "Crisis, Citizenship, and Cosmopolitanism: Living in a Local and Global Risk Society in Bali," Indonesia 75 (2013): 153-180; Teresa Lloro-Bidart, "A Political Ecology of Education in/for the Anthropocene," Environment and Society 6 (2015): 128-148; Mihaly Csikszentmihalyi, Philip Latter, and Christine Weinkauff Duranso, Running Flow (London: Human Kinetics, 2017).
} 
SMKN 1 Donorojo Pacitan membuat dua model masker yang sama-sama menggunakan bahan dasar kain. Model yang dibuat adalah model tali (untuk hijab maupun non-hijab atau biasa), dan model scuba yang menggunakan unsur budaya lokal. Hal tersebut tidak lepas dari kekayaan budaya Indonesia yang sudah dikenal dunia, yaitu Batik. Pengaplikasian motif batik dalam model masker scuba, diharapkan juga sebagai salah satu perwujudan penumbuhan bahwasanya kebudayaan turut serta dalam penanganan Covid-19.

Gambar 5. Model masker scuba.

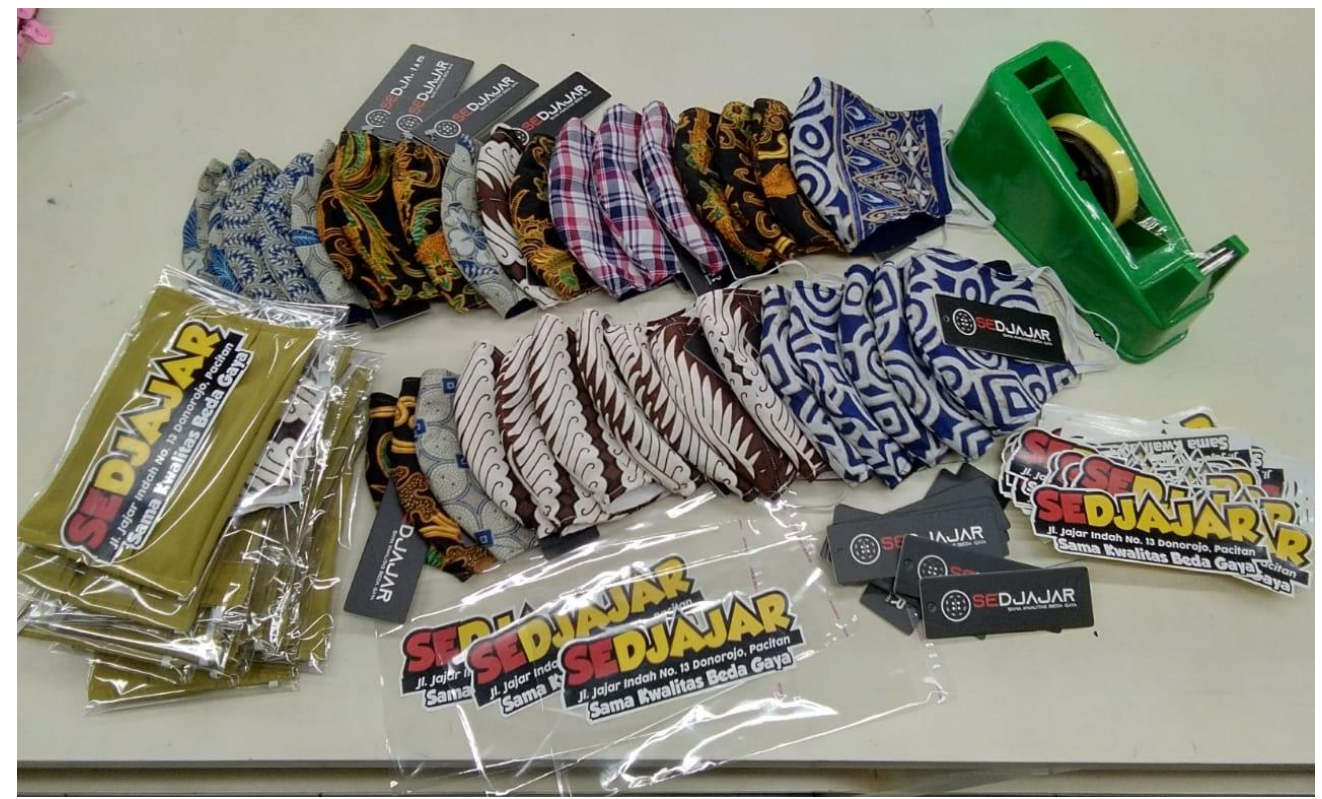

Sumber: Dokumentasi pribadi, 2020

Pembuatan masker oleh siswa SMKN 1 Donorojo dalam sudut pandang keterampilan kerja turut mendorong siswa untuk menyumbangkan sebagian dari keterampilan profesional mereka tanpa mengharapkan imbalan. Dengan demikian, muncul perilaku altruistis yang merupakan pusaran nilai pekerjaan sosial yang menekankan pentingnya dalam melayani masyarakat yang dalam keadaan yang dirugikan oleh bencana, dalam hal ini adalah masyarakat terdampak Covid-19. Lebih lanjut, pengabdian masyarakat adalah ciri khas pendidikan vokasional ${ }^{39}$. Pengetahuan siswa tentang esensi kemasyarakatan di komunitas diringkas dalam tinjauan praktis dalam pembuatan masker ini.

Kegiatan pengabdian kemasyarakatan ini juga menekankan aspek penting yang linier antara pendidikan, keterampilan, kemasyarakatan, dan budaya. Garis-garis antara pendidikan lapangan (penekanan pada pembelajaran praktis siswa), kesukarelaan (penekanan pada layanan), dan layanan-pembelajaran terlihat berkelindan dan saling kolaborasi dalam kegiatan ini. ${ }^{40}$ Lebih lanjut, pengalaman siswa dalam melayani

\footnotetext{
${ }^{39}$ Emmanuel de Kadt, “Arts, Crafts and Cultural Manifestations," Ekistics 48, no. 288 (2001): 244-
} 247.

${ }^{40}$ Lloro-Bidart, "A Political Ecology of Education in/for the Anthropocene." 
masyarakat berfokus terutama pada kegiatan langsung sehingga mampu memunculkan rasa empati.

Dari sudut pandang Jawa, dengan kegiatan kemasyarakatan maka guyub rukun memperlihatkan pandangan orang Jawa dalam melihat dunia secara kosmologi tentang dunia bagian bawah dan dunia bagian atas, sering dipadukan dengan dunia bagian tengah yang juga disebut dengan dualisme dwitunggal atau dualisme monostis ${ }^{41}$. Istilah tersebut cocok untuk disebutkan dalam implikasi kegiatan kemasyarakatan berbasis budaya guyub rukun, karena terjadi sinkretisme di dalamnya. Terlebih, paham simbolisme Jawa berupa mikrokosmos (manusia), makrokosmos (alam semesta), dan metakosmos (alam niskala yang tak nampak), terwujud dalam rasa tepo seliro yang muncul dari para pelaku kegiatan kemasyarakatan berbasis guyub rukun.

\section{KESIMPULAN}

Kebudayaan guyub rukun di era disrupsi dan dalam pandemi Covid-19 merupakan kebutuhan integratif, mencerminkan tentang keberadaan manusia sebagai makhluk berbudaya atau beradab. Hal tersebut disebabkan oleh sifat-sifat dasar manusia sebagai makhluk yang mempunyai pikiran, bermoral, bercita rasa, dan dapat mengintegrasikan berbagai kebutuhan menjadi suatu sistem yang dapat dibenarkan secara moral, dan dapat diterima oleh akal pikiran beserta cita rasanya.

Oleh karena itu, dalam kegiatan kemasyarakatan berbasis budaya guyub rukun melalui pembuatan masker oleh SMKN 1 Donorojo Pacitan ini memiliki kompleksitas. Kompleksitas tersebut sering kali tidak disadari, karena memang pada dasarnya kebutuhan kosmos manusia adalah saling membantu. Tidak hanya dalam hal kosmos manusia, kegiatan yang dilakukan oleh SMKN 1 Donorojo Pacitan dapat memunculkan rasa kerukunan, rasa kesatuan, semangat dan optimisme secara komunal khususnya dari masyarakat Kabupaten Pacitan dalam menghadapi pandemi Covid-19 ini.

\section{REFERENSI}

Adolph, K. E., and S. E. Berger. "Physical and Motor Development." In Developmental Science: An Advanced Textbook, edited by M. H. Bornstein and M. E. Lamb, 261-333. 7th ed. New York: Psychology Press/Taylor \& Francis, 2015.

Arifani, Moch. Anif. "Model Pengembangan Dakwah Berbasis Budaya Lokal." Jurnal Ilmu Dakwah: Academic Journal for Homiletic Studies 5, no. 15 (2010): 849-878. http://www.journal.uinsgd.ac.id/index.php/idajhs/article/view/425.

Arkin, Elaine Bratic. “Opportunities for Improving the Nation's Health through Collaboration with the Mass Media." Public Health Reports 105, no. 3 (1990): 219223.

Buana, Dana Riksa. “Analisis Perilaku Masyarakat Indonesia Dalam Menghadapi

${ }^{41}$ Lombard, Nusa Jawa: Silang Budaya (Warisan Kerajaan-Kerajaan Konsentris); Lombard, Nusa Jawa: Silang Budaya (Batas-Batas Pembaratan). 
Pandemi Virus Corona (Covid-19) Dan Kiat Menjaga Kesejahteraan Jiwa." SALAM: Jurnal Sosial dan Budaya Syar-i 7, no. 3 (2020).

Carretero, Mario, Stefan Berger, and Maria Grever, eds. Palgrave Handbook of Research in Historical Culture and Education. United Kingdom: Palgrave Macmillan, 2017.

Center for Disease Control and Prevention (CDC). "What You Need to Know about Coronavirus Disease 2019 (COVID-19)." Choice Reviews Online, 2020.

Cheung, Chau kiu, and wing whung Ho. "Investing in Community Participation to Receive Social Support." Journal of Social Service Research 38, no. 1 (2012): 110-123.

Choi, Sangmi, Hansung Kim, Moosung Chung, and Sun Young Lee. “Online Donation Experiences, Donation Awareness, and Intention of Future Donation Among Teenagers in South Korea." Journal of Social Service Research 45, no. 5 (2019): 622-633. https://doi.org/10.1080/01488376.2018.1487363.

Cnaan, Ram A., and Carl Milofsky, eds. Handbook of Community Movements and Local Organizations. Singapore: Springer, 2007.

Connor, Linda, and Adrian Vickers. "Crisis, Citizenship, and Cosmopolitanism: Living in a Local and Global Risk Society in Bali." Indonesia 75 (2013): 153-180.

Creswell, John W. Research Design Pendekatan Kualitatif, Kuantitatif, Dan Mixed. Yogyakarta: Pustaka Pelajar, 2010.

Csikszentmihalyi, Mihaly, Philip Latter, and Christine Weinkauff Duranso. Running Flow. London: Human Kinetics, 2017.

Dávila, María Celeste. "The Relationship between Social Networks and Volunteerism among Seniors." Journal of Social Service Research 44, no. 1 (2018): 38-49. https://doi.org/10.1080/01488376.2017.1395382.

Denzin, Norman K., and Yvonna S. Lincoln, eds. The SAGE Handbook of Qualitative Research. Fifth Edit. Los Angeles: Sage Publications, 2018.

Dwiyasmono. "Karya Tari 'Solah' Refleksi Nilai-Nilai Budaya Jawa Dalam Kehidupan Kekinian." Jurnal Kawistara 5, no. 1 (2015).

Geertz, Clifford. The Interpretation of Cultures. New York: Basic Book, 1973.

Glăveanu, Vlad Petre, ed. The Palgrave Handbook of Creativity and Culture Research. United Kingdom: Palgrave Macmillan, 2016.

Hommerová, Dita, and Lucie Severová. "Fundraising of Nonprofit Organizations: Specifics and New Possibilities." Journal of Social Service Research 45, no. 2 (2019): 181-192. https://doi.org/10.1080/01488376.2018.1479678.

Huang, Hui, Sofia Fernandez, Michelle Ann Rhoden, and Rigaud Joseph. "Serving Former Foster Youth and Homeless Students in College." Journal of Social Service Research 8376 (2018): 1-14. https://doi.org/10.1080/01488376.2018.1441096.

Huda, M. Thoriqul. "Harmoni Sosial Dalam Tradisi Sedekah Bumi Masyarakat Desa Pancur Bojonegoro." Religió: Jurnal Studi Agama-agama 7, no. 2 (2017): 267-296.

James, Kaufman, and Robert J. Sternberg. The Cambridge Handbook of Creativity. New York: Cambridge University Press, 2010.

Johnson, Michael P. Community-Based Operations Research: Decision Modeling for Local 
Impact and Diverse Populations. Singapore: Springer, 2012.

Kadt, Emmanuel de. "Arts, Crafts and Cultural Manifestations." Ekistics 48, no. 288 (2001): 244-247.

Kemkes. “Tentang Novel Coronavirus (NCOV)." Last modified 2020. Accessed April 3, 2020. https://www.kemkes.go.id/resources/download/info-terkini/COVID19/TENTANG NOVEL CORONAVIRUS.pdf.

Ki Hadjar Dewantara. Karya Ki Hadjar Dewantara Bagian I: Pendidikan. Yogyakarta: Majelis Luhur Persatuan Taman Siswa, 2004.

Klein, Sheri R. "Humor in a Disruptive Pedagogy Further Considerations for Art Educators." Art Education 66, no. 6 (2013): 34-39.

Kumar, Dharmendra, Rishabha Malviya, and Pramod Kumar Sharma. "Corona Virus: A Review of COVID-19." Eurasian Journal of Medicine and Oncology 4, no. 2 (2020): 825.

Kusumawardhani, Ika Amalia, Woro Kurnianingrum, and Naomi Soetikno. "Art Therapy Untuk Meningkatkan Kontrol Diri Pada Anak Didik Lapas." Jurnal Muara Ilmu Sosial, Humaniora, dan Seni 2, no. 1 (2018): 135.

Lloro-Bidart, Teresa. "A Political Ecology of Education in/for the Anthropocene." Environment and Society 6 (2015): 128-148.

Lombard, Dennys. Nusa Jawa: Silang Budaya (Batas-Batas Pembaratan). Jakarta: Gramedia Pustaka Utama, 2008.

- - . Nusa Jawa: Silang Budaya (Warisan Kerajaan-Kerajaan Konsentris). Jakarta: Gramedia Pustaka Utama, 2008.

Moran, Joe. Interdisciplinarity. New York: Routledge, 2002.

Mukharom, Mukharom, and Havis Aravik. "Kebijakan Nabi Muhammad Saw Menangani Wabah Penyakit Menular Dan Implementasinya Dalam Konteks Penanggulangan Coronavirus Covid-19." SALAM: Jurnal Sosial dan Budaya Syar-i 7, no. 3 (2020).

Ruliana, Vita, Roekmijati W. Soemantojo, and Donna Asteria. "Assessing a CommunityBased Waste Separation Program through Examination of Correlations between Participation, Information Exposure, Environmental Knowledge, and Environmental Attitude." ASEAN Journal of Community Engagement 3, no. 1 (2019): $1-27$.

Rutter, M., and N. Garmezy. "Developmental Psychopathology." In Handbook Of Child Psychology. 4th ed. New York: Wiley, 1983.

Sampurno, Muchammad Bayu Tejo, Tri Cahyo Kusumandyoko, and Muh Ariffudin Islam. "Budaya Media Sosial, Edukasi Masyarakat, Dan Pandemi COVID-19." SALAM: Jurnal Sosial dan Budaya Syar-i 7, no. 5 (2020).

Scripps Research Institute. "COVID-19 Coronavirus Epidemic Has a Natural Origin." Science Daily. Last modified 2020. Accessed April 3, 2020. https://www.sciencedaily.com/releases/2020/03/200317175442.htm.

Shkedi, Asher. Introduction to Data Analysis in Qualitative Research. Singapore: Springer International Publishing, 2019. 
Somekh, Bridget. Action Research: A Methodology for Change and Development. Berkshire: Open University Press, 2006.

Strand, Kerry J., Nicholas Cutforth, Randy Stoecker, Sam Marullo, and Patrick Donohue. Community-Based Research and Higher Education: Principles and Practices. New York: Jossey-Bass, 2003.

Syandri, Syandri, and Fadhlan Akbar. "Penggunaan Masker Penutup Wajah Saat Salat Sebagai Langkah Pencegahan Wabah Coronavirus Covid-19." SALAM: Jurnal Sosial dan Budaya Syar-i 7, no. 3 (2020).

Syarifah, Masykurotus. "Budaya Dan Kearifan Dakwah." al-Balagh: Jurnal Dakwah dan Komunikasi 1, no. 1 (2016): 23.

Tashakkori, A, and J Creswell. "Mixed Methodology Across Disciplines." Journal Of Mixed Methods Research 2, no. 1 (2008): 1-5.

Wilcox, Emily E. "Beyond Internal Orientalism: Dance and Nationality Discourse in the Early People's Republic of China, 1949-1954." Journal of Asian Studies 75, no. 2 (2016): 363-386.

Winton, Sue. "The Appeal(s) of Character Education in Threatening Times: Caring and Critical Democratic Responses." Comparative Education 44, no. 3 (2018): 305-316.

World Health Organization. "Coronavirus." Last modified 2020. Accessed April 3, 2020. https://www.who.int/health-topics/coronavirus\#tab=tab_1.

Yunus, Nur Rohim, and Annissa Rezki. "Kebijakan Pemberlakuan Lock Down Sebagai Antisipasi Penyebaran Corona Virus Covid-19." SALAM: Jurnal Sosial dan Budaya Syar-i 7, no. 3 (2020).

Zahrotunnimah, Zahrotunnimah. "Langkah Taktis Pemerintah Daerah Dalam Pencegahan Penyebaran Virus Corona Covid-19 Di Indonesia." SALAM: Jurnal Sosial dan Budaya Syar-i 7, no. 3 (2020).

Zhou, Wang, ed. Coronavirus Prevention Handbook. Wuhan: Hubei Science and Technology Press, 2020.

“Covid-19 Coronaviruses Pandemic." Accessed April 3, 2020. https://www.worldometers.info/coronavirus/.

“Jenis-Jenis Masker." Accessed May 15, 2020. https://www.alodokter.com/inilahpilihan-masker-untuk-virus-corona.

"Penggunaan Masker." The Jakarta Post. Accessed May 15, 2020. https://www.thejakartapost.com/news/2020/04/06/face-masks-a-must-in-publicplaces-says-indonesias-covid-19-rapid-response-team.html.

“Sebaran Covid19.” Accessed May 15, 2020. https://covid19.go.id/. 